\title{
LA URNA DE CAREY DEL SANTO SEPULCRO DE LOGROÑO
}

\section{THE TORTOISESHELL URN OF THE HOLY SEPULCHRE OF LOGROÑO}

\author{
Fermín LABARGa \\ Universidad de Navarra. España \\ flabarga@unav.es
}

\begin{abstract}
En la concatedral de Santa María de la Redonda de Logroño se conserva el legado de don Gabriel de Unsain, donado en 1694 para establecer la función del Descendimiento el Viernes Santo. Del conjunto, compuesto por una talla de Cristo yacente de buena factura y una imagen de vestir de la Virgen de la Soledad, destaca la magnífica urna de carey, ébano y plata. Relacionada hasta ahora con modelos sevillanos, la aparición del contrato sitúa su ejecución en Valladolid en 1693. Con traza de Blas Martínez de Obregón, es obra de los maestros ebanistas Sebastián Ramírez y Antonio Ferrel.

Palabras clave: Logroño; urna del Santo Sepulcro; Blas Martínez de Obregón; Sebastián Ramírez; Antonio Ferrel.
\end{abstract}

One of the art treasures of the Co-cathedral of Santa María de la Redonda of Logroño is the Holy Sepulchre, a heritage of Gabriel de Unsain, donated in 1694 for the purpose of establishing the religious ceremony of the Descent from the Cross on Good Friday. Within the whole composition, consisting of a well crafted carving of the Lying Body of Christ and a dressed carving of Our Lady of Solitude, stands out the magnificent urn of the Holy Sepulchre, made of tortoiseshell, mahogany and silver. While formerly the urn was related to Sevillian models, the recent discovery of the contract shows that it was made in Valladolid in 1693. Blas Martínez de Obregón did the design and the carpentry masters Sebastián Ramírez and Antonio Ferrel made the urn.

Keywords: Logroño; urn of the Holy Sepulchre; Blas Martínez de Obregón; Sebastián Ramírez; Antonio Ferrel.

\section{INTRODUCCIÓN}

En la capilla de los Ángeles de la concatedral de Santa María de la Redonda de Logroño, se muestra a la veneración de los fieles en un retablo de finales del siglo XVIII la imagen del Cristo yacente en una soberbia urna de carey que, al igual 
que la imagen de la Virgen de la Soledad, fue donada en 1694 por don Gabriel de Unsain. En unas pequeñas chapas de plata situadas en la base de la urna se indican el nombre y el año de la donación: "Diólo y dotólo el capitán don Gabriel de Unsain...". Del mismo modo, en el archivo de la antigua colegial se guardaba "la escritura de donación graciosa del Santo Sepulcro e imagen de Nuestra Señora de la Soledad, hecha por don Gabriel y don Blas de Unsain al Cabildo desta Insigne Colegial en veinte de marzo de mil seiscientos y noventa y cuatro por testimonio de Mathias de Legaria, escribano desta ciudad"1.

Existe en España un notable conjunto de urnas sepulcrales destinadas a albergar la imagen de Cristo yacente, utilizadas por lo general en la procesión del Santo Entierro. Entre dichas piezas, destacan por su valor artístico unas pocas cuya principal característica es la de estar ricamente recubiertas con concha de carey, un material costoso y raro en estos lares, no así en tierras americanas, principalmente las del antiguo virreinato de Nueva España. En dicho conjunto debe incluirse la de Logroño, de la que se ha podido documentar muy recientemente la autoría gracias al descubrimiento, tras una paciente labor de rastreo documental, del contrato de ejecución, fechado en Valladolid en el año de 1693. En este artículo se ofrecen los datos referentes a la magnífica pieza y su proceso de ejecución así como al donante que la hizo posible y los artistas que la elaboraron. Hasta muy recientemente, en que se ha acometido un estudio profundo y serio, nada se sabía sobre el particular, abundando los datos erróneos.

Constituye, además, una gran satisfacción poder ofrecer la datación de esta pieza excepcional con ocasión del merecido homenaje que se rinde a la larga y fructífera trayectoria académica del querido profesor Juan Miguel González Gómez.

\section{EL DONANTE, DON GABRIEL DE UNSAIN, Y SU MAGNÍFICA DONACIÓN}

Gabriel de Unsain nace en Logroño en 1644 en el seno de una familia modesta de agricultores y pequeños comerciantes; cincuenta años después legará a su ciudad natal el magnífico conjunto conformado por el Santo Sepulcro, el Cristo yacente, la imagen de la Virgen de la Soledad y todo lo demás necesario para la celebración del descendimiento. En mayo de 1698 fallecía en Sevilla, en su domicilio de la collación de San Ildefonso².

\footnotetext{
${ }^{1}$ Archivo Histórico Diocesano de Logroño (A.H.D.L.), Logroño, Santa María de la Redonda, Libro 65 de la Mesa Capitular, f. 94.

2 Archivo de la Parroquia de San Ildefonso de Sevilla, Libro $2^{\circ}$ de entierros de la Iglesia Parroquial del Sr. San Ildephonso de esta ciudad de Sevilla, desde el año de 1638 hasta e de 1768, f. 382. Pueden verse los datos biográficos del donante en LABARGA, Fermín: Diolo y dotolo. El legado de don Gabriel de Unsain y la Semana Santa de Logroño. Logroño, 2015, pp. 19-72.
} 
Cuatro años antes, el 20 de marzo de 1694, representado por su hermano don Blas, beneficiado de la iglesia de San Bartolomé, don Gabriel de Unsain otorgaba ante el escribano Matías de Legaria la escritura de donación del Santo Sepulcro, una talla articulada de Cristo, la imagen de Nuestra Señora de la Soledad y demás efectos necesarios para celebrar cada año el día de Viernes Santo la función del descendimiento. La donación se efectuaba a favor de Iglesia Colegial de Logroño según se indicaba de manera expresa en la escritura:

"Habiendo premeditado el sitio más decente y cómodo, y tomando parecer de personas de toda confianza y cristiano celo, me pareció muy conveniente colocarlo en la Iglesia Colegial para que en ella y por los Señores Deán y Cabildo se hiciese la función del Descendimiento, pues con religioso y ejemplar celo lo ejecutarán con el culto y reverencia que acostumbran en las demás festividades de su iglesia"'.

Tal y como sigue indicando la escritura, el motivo que había dado lugar a la donación no era otro que "la particular devoción que ha tenido y tiene [don Gabriel] en contemplar los dolorosos misterios de la Pasión de Nuestro Señor Jesucristo y, en especial, el de su sepultura, y asimismo la Soledad de la Serenísima Reina de los Ángeles, su Santísima Madre, con cuya devoción y memoria ha conseguido repetidos favores de su Divina Misericordia, librándole de manifiestos peligros, así en estos reinos como en los de Nueva España”.

Entre los cuales se contaría, sin duda, la pavorosa tormenta que le sorprendió en el mar Caribe cuando regresaba a España en los galeones al mando del marqués del Vado del Maestre en 1691. Por ello, "deseando que la dicha devoción como tan provechosa y espiritual se imprima en los corazones de todos los católicos, y que en toda la ciudad se hiciese el día de Viernes Santo de cada año particular función de pasos tan lastimosos, según se ejecutan en las ciudades principales de estos reinos, y para celebrar con viva representación el paso del Descendimiento de Nuestro Redentor y su sepultura, solicitó hacer por su cuenta la hechura del Santo Cuerpo de Jesús crucificado de cuerpo entero, y otra de la Santísima Madre de la Soledad con movimientos y tornillos en los brazos y una urna que hubiese de servir de Santo Sepulcro del Sagrado Cuerpo".

Junto con las piezas mayores y principales, el legado incluía además "una hechura de la Santa Cruz y tornillos necesarios para poner en forma de crucificación el soberano Cuerpo de Jesús, varias almohadas de terciopelo negro, un manto de anascote para la Soledad y unas andas de pino para llevarlas a hombros con ocho almohadillas, y también dos escalas que sirvan para el descendimiento y un tablado para que más cómodamente se ejecute".

3 A.H.D.L., Logroño, Santa María de la Redonda, Libro de la Mesa Capitular. Año 1703, f. 94; y Libro perteneziente a los efectos de el Santo Sepulchro de esta Insigne Iglesia Colegial de Logroño, f. 1v. 
La escritura no indica el nombre de los artistas a los que se encargaron las imágenes ni la urna, pero asegura haberse valido "de los más primorosos artífices de estos reinos, los cuales, y cada uno de por sí, han ejecutado todo con el primor que ha podido ser dable, en que ha tenido de costa todo ello muy crecida suma". Lo cual, sin forzar la expresión, parece remitir a artistas foráneos. Sin aventurar demasiado es posible afirmar que el conjunto se fue conformando progresivamente según se iban encargando las diferentes piezas. De acuerdo con una hipótesis razonable, en primer lugar se encargarían la talla del yacente y la imagen de la Virgen de la Soledad; luego, la urna, cuya labor de ebanistería se realizó en Valladolid y se completó, quizás, ya en Logroño con los adornos de plata.

Como ya se ha indicado, desde su tormentoso regreso de América, Unsain venía acariciando la idea de realizar una especie de ofrenda o ex voto. Estos deseos bien pudieron concretarse en la idea de regalar a su ciudad natal de Logroño todo lo necesario para realizar la función del Descendimiento y una majestuosa procesión en la tarde del Viernes Santo al conocer la actividad desbordante que en esos años se observaba en el seno de la cofradía hispalense del Santo Entierro, incluyendo la adquisición de nuevas piezas artísticas, gracias al magnífico impulso que le venía dando el presbítero don Manuel González de Contreras. A lo largo del año 1692 fueron realizándose los nuevos pasos e imágenes que se estrenaron en la estación de penitencia del año siguiente, que resultó singularmente brillante, según refería una relación de los hechos redactada por Juan Gómez de Prado $^{4}$. Entre los estrenos destacaba una valiosa urna revestida de concha de carey, realizada por el maestro Francisco de Humanes Padilla, que a la sazón era también oficial de su junta ${ }^{5}$.

¿Fue éste el detonante último que llevó a Gabriel de Unsain a instaurar en Logroño la función del descendimiento y a dotarla de las piezas necesarias, entre las que se incluía obviamente una urna semejante? No es posible asegurarlo con total certeza, pero resulta bastante probable.

\section{LA URNA DEL SANTO SEPULCRO}

Existe unanimidad al concluir que de todo el conjunto del legado de Unsain, sin duda, sobresale por su elegancia y riqueza la soberbia urna del Sepulcro, cuya alma de madera de pino ha sido recubierta por su parte externa de chapas de

${ }^{4}$ Ha sido publicada en varias ocasiones. La tomo de CARRERO RODRÍGUEZ, Juan: "Antecedentes históricos de la Hermandad del Santo Entierro", en Manifiesto de la Hermandad del Santo Entierro. Magna Procesión de 1992. Sevilla. Sevilla, 1992, pp. 17-20.

5 CARRERO RODRÍGUEZ, Juan: Anales de las Cofradias Sevillanas. Sevilla, 1984, pp. 516-528; y MESTRE NAVAS, Pablo Alberto: Historia de la Real Hermandad del Santo Entierro de Sevilla: del colegio de San Laureano al de San Gregorio de los Ingleses. Sevilla, 2010, pp. 84-105. 
carey, completándose luego con molduras de ébano y apliques de plata cincelada. Se trataba de una "una urna que hubiese de servir de Santo Sepulcro del Sagrado Cuerpo", que la escritura de donación consignaba como "una caja toda ella de concha fina y ébano, guarnecida de plata de martillo y doce ramos de filigrana de plata con sus macetas de boj los ocho ramos grandes y los cuatro pequeños, rodeada de vidriera de cristal fino".

Ruperto Gómez de Segura en su clásica obra Las Parroquias de Logroño la describía de la siguiente manera:

"Es una caja prismática rectangular de madera rica y chapeada de concha en las superficies planas, con molduras negras y aplicaciones de bronce, franqueada en las aristas verticales por columnillas salomónicas de capitel corintio en bronce y terminadas en pedestalitos para jarritas con flores de plata. En estos remates encaja la tapa de forma tumbada y todo el conjunto está cerrado por cristalería fina. La escultura de Cristo Muerto es de las buenas de su tiempo por su modelado y pintura de encarnación.

Todo es notable de proporción, buen gusto y riqueza"6.

Para perpetuo recuerdo del donante y la fecha de donación se grabó en cuatro chapitas de plata situadas en la basa de la urna la siguiente leyenda:

"Diolo y dotolo el capitán d. Gavriel de Unsain - Regidor Perpetuo de esta Ciudad - Familiar del Santo Oficio de la Inquisición - año 1694”.

La urna tiene unas medidas de $217 \mathrm{~cm}$ de longitud, 130 de altura y 129 de profundidad, incluyendo la tapa. Su estructura, o alma, está fabricada en madera de pino de Soria. Consta de dos piezas: la urna y la tapa. La urna consiste en una caja rectangular dispuesta sobre una moldura a modo de entablamento con ángulos achaflanados en los que se sitúan columnas salomónicas pareadas, con capiteles corintios, apeadas sobre plintos apilastrados, y sobre las que descansan otros tantos pedestales sobre los que se sitúan floreros de ébano en los que se insertan ramos de azucenas en filigrana de plata. Todos los frentes se cubren con vidrios emplomados, cinco en los lados mayores y tan solo uno en los menores.

La tapa es tronco-piramidal y tiene una altura de $44 \mathrm{~cm}$. Se ajusta sobre la urna y cubre sus vanos con cristales; remata en cuatro pequeños con floreros de ébano con minúsculos ramos de azucenas en filigrana de plata, similares a los que hay sobre la urna.

Por su parte externa, todo ello está recubierto de chapas de carey. Las molduras son de ébano y los apliques - que juegan la doble función de sujetar las piezas y de enriquecer plásticamente el conjunto-, cantoneras, basas, capiteles y perfiles de sujeción de los cristales están labrados en plata de ley. Rematando los pares de columnas, en jarritas de boj aparecen ocho ramilletes de filigrana de plata, al igual que otros cuatro más pequeños sobre la tapa de la urna.

${ }^{6}$ GÓMEZ DE SEGURA, Ruperto: Las tres parroquias de Logroño. Logroño, 1930, p. 53 . 
El conjunto resulta primoroso no solo por el trabajo de la plata sino fundamentalmente por el del carey, siendo la mejor pieza en su género existente en La Rioja y una de las mejores de toda España, si bien es cierto que hasta ahora poco conocida. Es de lamentar que una pieza tan singular y valiosa como la urna de carey existente en la Redonda se halle ausente, sin embargo, de manera sistemática en las publicaciones sobre el arte y el patrimonio riojano aparecidas en los últimos años. Nada se dice de esta pieza al tratar sobre el periodo barroco ni tampoco al consignar piezas de origen foráneo, de manera especial las ejecutadas con materiales ricos procedentes de América, entre las que sí se incluyen paradójicamente algunas piezas menores de carey.

El carey, según el Diccionario de la Real Academia de la Lengua, en su segunda acepción, es la "materia córnea que se saca en chapas delgadas calentando por debajo las escamas del carey", que se utilizó como material ornamental para piezas nobles. En la ciudad de México y en otras principales de la Nueva España se comerciaba el carey para su exportación a la metrópoli y su posterior venta en Sevilla o Cádiz. Además de la fabricación de pequeños utensilios, como espejos o peines, y de arcas y cofres para joyas, el carey sirvió también para la decoración de muebles ricos. Otra vertiente de la artesanía del carey es la dirigida a la confección de objetos piadosos, como cruces que en ocasiones alcanzan un tamaño considerable. En todos estos casos, las láminas de carey servían para recubrir el armazón de madera que daba forma a la estructura. Este es el caso del Sepulcro de Logroño y de otros similares que existen en Andalucía, como los de Écija y Utrera.

Resta indicar que por las fechas en que se mandó fabricar la urna logroñesa el carey era un producto caro; en 1684 una libra -es decir, algo menos de medio kilo- costaba 26 reales de plata según el inventario y tasación de los bienes del ebanista madrileño Juan de Salinas ${ }^{7}$. Quizás debido a la constante devaluación de la moneda, en 1691 el precio que se pagaba en Sevilla por una libra de carey casi duplicaba esa cantidad ${ }^{8}$.

Con todo y a pesar de lo que yo mismo he sostenido con anterioridad ${ }^{9} \mathrm{y}$ de lo que otros autores también sospechaban a raíz de las semejanzas morfológicas

7 AGUILÓ AlONSO, María Paz: El mueble en España, siglos XVI-XVII. Madrid, 1993, pp. 30 y 72.

8 Archivo Histórico Provincial de Sevilla, sig. 1859P, ff. 533-534v.

9 LABARGA GARCÍA, Fermín: "El Santo Sepulcro de Logroño", en Actas del Tercer Encuentro para el estudio cofradiero: en torno al Santo Sepulcro. Zamora, 1995, pp. 313320; "El Santo Sepulcro de Logroño. Probable obra sevillana del s. XVII", Boletín de las cofradías de Sevilla, 430, 1995, pp. 65-66; y "Un ejemplo del trasvase artístico y religioso desde la ciudad de Sevilla a Logroño a finales del siglo XVII", en REDER GADOW, Marion (coord.): Actas del Congreso sobre la Andalucía de finales del siglo XVII. Cabra, 1999, pp. 295-310. 
y estilísticas ${ }^{10}$, la urna del Santo Sepulcro de Logroño no fue realizada en Sevilla sino en Valladolid.

Tras la revisión meticulosa de los protocolos sevillanos de los años comprendidos entre 1690 y 1694, que me ofrecieron abundantes datos sobre la actividad comercial de Gabriel de Unsain pero nada referente a la donación, comencé a inclinarme por otra vía de investigación que me remitía a Valladolid. ¿Qué fue lo que me llevó a optar por esta nueva y, a priori, poco probable localización -incluso por la absoluta ausencia de trabajos específicos del carey en dicha ciudad castellana-? En el revestimiento de plata del plinto de una de las columnillas aparece marcada con punzón la siguiente leyenda: "Blas Martínez, Ballad"”. Conviene advertir, en primer lugar, de que no se trata de marcas de platero -como erróneamente se señala en el informe de la restauración- sino del nombre del autor de la traza: el "maestro de arquitectura" de retablos y ensamblador Blas Martínez de Obregón.

¿Era Blas Martínez de Obregón el autor de la pieza? No me parecía probable ya que no se dedicaba a este tipo de labores. Sin embargo, decidí bucear también en Valladolid en el Archivo de Protocolos Notariales para ver si esta vez había suerte y aparecía la documentación buscada. De nuevo, en otra larga y paciente labor de rastreo de los protocolos notariales en el Archivo Provincial de Valladolid pude, al fin, dar con el contrato.

El contrato confirmaba que fue Blas Martínez de Obregón quien realizó en abril de 1693 la traza de la urna del sepulcro por encargo de don Blas de Unsain. Para este momento, contaba ya con cierto prestigio dentro del mundo artístico de Valladolid, donde había realizado el retablo del colegio de los Ingleses, el de la capilla del Rosarillo y varios del convento de San Quirce ${ }^{11}$. Tenía su casa taller "enfrente de la Casa Profesa de la Compañía de Jesús de san Ignacio desta ciudad", en un edificio alquilado a don Diego de Soria ${ }^{12}$. Poco después, ya en 1694, comenzaría la construcción del retablo mayor de la iglesia de Santiago de Villalba de los Alcores ${ }^{13}$.

${ }^{10}$ CARRERO RODRÍGUEZ, Juan, "La urna del Santo Entierro de Sevilla y otras de España, en ricos materiales", Boletín de las cofradías de Sevilla, 447, 1996, p. 30; GARCÍA LEÓN, Gerardo: ficha catolográfica de la urna del Santo Entierro de Écija, en PLEGUEZUELO, Alfonso y VALDIVIESO, Enrique (coords.): Teatro de grandezas. Sevilla, 2007, p. 292; y AGUILÓ, María Paz, "Una aportación a la ebanistería granadina en la segunda mitad del siglo XIX”, Archivo Español de Arte, 328, 2009, p. 418.

${ }^{11}$ MARTÍN GONZÁLEZ, Juan José: El retablo barroco en España. Madrid, 1993, p. 103.

12 GARCÍA CHICO, Esteban: Documentos para el estudio del arte en Castilla, II: Escultores. Valladolid, 1941, p. 359.

13 PARRADO DEL OLMO, Jesús María: "La colaboración entre ensambladores en los proyectos de los retablos de finales del siglo XVII y unas obras inéditas de Tomás de Sierra", Boletín del Seminario de Estudios de Arte y Arqueología, 62, 1996, pp. 401-420. 
Con la traza ejecutada por Martínez de Obregón, don Blas de Unsain concertó también en Valladolid la ejecución de la urna con los ebanistas Sebastián Ramírez y Antonio Ferrel. El contrato se firmó ante el escribano Manuel de Tudanca el 28 de abril de $1693^{14}$.

Resulta realmente sorprendente que estos dos ebanistas fueran capaces de fabricar una pieza tan exquisita como el Sepulcro logroñés. Debían ser expertos conocedores del arte de trabajar el carey, nada sencillo, máxime en una ciudad como Valladolid donde no abundaban los encargos en este material. No se conservan datos de ninguno de los dos salvo que Antonio Ferrel fue alcalde de la Cofradía Penitencial de Nuestro Padre Jesús Nazareno precisamente en aquel año de 1693.

El 28 de abril - por tanto, poco después de la Semana Santa- el "licenciado don Blas de Unsain, clérigo presbítero vecino de la ciudad de Logroño, residente a el presente en esta de Valladolid" concertaba con Sebastián Ramírez y Antonio Ferrel "la obra de una urna y entierro para el Sepulcro" de acuerdo con una serie de condiciones:

"Que toda la parte de fuera de dicha urna y entierro ha de ser de concha y ébano, según está hecho el apuntamiento en la traza.

Que dicha obra se ha de ejecutar conforme el perfil de la traza guardando todos sus resaltos y macizos según arte.

Que las colunas salomónicas se han de ejecutar conforme arte y ha de llevar sus pilastras en cada una con su vaciado de moldura en el fondo de concha y juntamente la cornisa principal ha de guardar todos los resaltos que le tocan según sus desminuziones de la coluna.

Que dicha urna se ha de aparejar en blanco toda de madera de Soria, así bastidores como cornisa y pedrestal ha de ser ensamblado de buen ensamblaje elijido para que en ningún tiempo falte ni se desuna del material de la concha y ébano ni lo demás que en ella se aplacare.

Que la obra se ha de cubrir en esta forma: por la parte de adentro ha de ser toda de palosanto seco y todos los bastidores han de ir perfilados de box y, juntamente, la cornisa que va por la parte de afuera ha de correr por la parte de adentro mudando de perfil por no poder ser según la de afuera y en el friso de la cornisa ha de ir todo perfilado de box.

Que las pilastras han de corresponder por la parte de adentro según las de afuera con sus basas de box y collarinos y cimacios según arte y las pilastras con su vaciado y en el fondo perfilado de box.

Que todos los resaltos de las pilastras por adentro se han de amplafonar debajo de las molduras que se ponen del miembro bajo. Y la corona de la cornisa ha de pasar derecha porque no puede llevar resalto.

${ }^{14}$ Archivo Histórico Provincial de Valladolid, Protocolos Notariales 2432, ff. 650$651 \mathrm{v}$. 
Que para asentar el efigie [del Cristo yacente] dentro de la urna se ha de hacer su colado cubierto de palosanto con su moldura que haga cornisa y el liso que pueda perfilado de box y esto es para que se descubra y no le tape el alto del bastidor.

Que las molduras para los vidrios que han de llevar por la parte de fuera han de ser también por la parte de adentro y todas de palosanto.

Que dicha obra se ha de ejecutar en blanco con todo el arte necesario sin que tengan obligación los otorgantes de poner bronces ni vidrios ni otra cosa tocante al adorno sino es en la forma que va referido.

Que todo el material ha de ser muy bueno y, en especial, la concha porque si alguna disonare mucho de la otra la han de quitar y poner igual.

Que dicha obra se ha de ejecutar según la traza que queda firmada de los otorgantes y del dicho Licenciado don Blas de Unsain en poder de los dichos Sebastián Ramírez y Antonio Ferrel sin quitar ni añadir la forma, que aunque en dicha obra se hagan mejoras no se han de poder pedir ni pagar más que tan solamente la cantidad que irá declarada y en caso que se hagan mejoras las han de perder los dichos maestros.

Que acabada dicha obra se ha de entregar en esta Ciudad encajonada en cajones de tablas para que sin riesgo alguno lo puedan llevar a la dicha Ciudad de Logroño las personas que lo llevaren.

Que dicha obra habiéndose acabado la han de ver maestros peritos en el arte de ebanistas nombrados por cada parte el suyo y si no estuviere ejecutada conforme la traza y condiciones referidas han de ser obligados y apremiados los otorgantes a cumplirla y ejecutarla en todo como va referido.

Que el largo, alto y ancho a de ser según las medidas que a los otorgantes entrega el dicho Licenciado don Blas de Unsain firmadas, las cuales junto con la traza se han de manifestar habiéndose acabado dicha obra para que se reconozca si se ha cumplido en todo con ella y se han de entregar a el dicho Licenciado don Blas de Unsain.

Que toda la dicha obra la han de dar acabada en toda perfección para fin de junio que vendrá de este año de noventa y tres, puesta y entregada en esta Ciudad. Y no lo cumpliendo, ansí se les ha de apremiar por todo rigor de derecho a que la acaben de cumplir y ejecutar además de que se les ha de rebajar un mil reales del precio principal en que se ha concertado dicha obra. Y también pueda el dicho licenciado don Blas de Unsain buscar otros maestros que la acaben y por lo que más costare se ha de poder ejecutar a los otorgantes con solo la declaración jurada del dicho Licenciado don Blas de Unsain y de los maestros que la acabaren sin otro instrumento de que le relevan y también apremiarles y ejecutarles por las cantidades que hubieren recibido por cuenta de dicha obra, rebajando solo lo que hubieren obrado en ella, usando de cualquier derecho de los que van referidos".

Respecto al importe, se convenía que "por razón de toda la dicha obra a toda costa de mano y materiales se han de dar y pagar a los otorgantes seis mil y quatrocientos $\mathrm{R}^{\mathrm{s}}$ de vellón". La cantidad se entregaría en cuatro plazos: al contratarla, 
don Blas de Unsain entregaba 3.000 reales; quince días después, otros seiscientos; mil más cuando estuviera mediado el trabajo; y, por último, "lo restante [1.800 reales] habiéndose cumplido con haber acabado dicha obra y dádose por buena a vista de maestros como va referido".

Del contrato puede inferirse que ya se contaba con la imagen del Cristo yacente, cuyas dimensiones determinan las de la urna, y que no se contrata la labor de platería. Cabe suponer que fuera ya en Logroño donde se realizaron los trabajos de platería e, igualmente, donde se le colocaron los vidrios correspondientes. El impacto que supuso fue grande, por su valor artístico y material.

Gracias a la generosidad de don Gabriel de Unsain, Logroño contaba con una pieza excepcional comparable a la magnífica urna de la cofradía del Santo Entierro de la ciudad de Sevilla, ejecutada por Francisco Humanes Padilla, estrenada en ese mismo año de 1693 y lamentablemente desaparecida durante la Invasión francesa ${ }^{15}$. Existe un grabado que -aunque tosco- permite hacerse una idea de cómo era realmente aquella urna fabricada para la hermandad hispalense: caja acristalada con columnas salomónicas en sus extremos.

Cabe pensar igualmente que algunas urnas se inspiraron en esta soberbia pieza sevillana, como la encargada por la hermandad de Nuestra Señora de la Soledad y Santo Entierro del antiguo convento del Carmen Calzado de Écija al ebanista sevillano Cristóbal de Yepes ${ }^{16}$, que según García León, "constituye un impecable trabajo de ebanistería que alcanza cotas casi preciosistas en la adaptación de las planchas de carey a los más intrincados detalles arquitectónicos y la convierten en un verdadero mueble joya, sobre todo tras recibir el conjunto de adornos de platería". No debe olvidarse tampoco "la solemnidad de su apariencia" ni "el efectismo y la teatralidad barroca de su diseño arquitectónico -un tanto arcaizante para su época-". Sin lugar a dudas, una pieza excepcional de la cual se afirma explícitamente que "guarda notables paralelismos, en cuanto a morfología, diseño y materiales, con la urna del Santo Entierro de Logroño"17.

Guarda también alguna relación con la desaparecida sevillana, la urna de carey de la antigua cofradía de Nuestra Señora de la Soledad y Santo Entierro de

15 Archivo Histórico Provincial de Sevilla, sig. 1859P, ff. 533-534v.

${ }^{16}$ HERNÁNDEZ DÍAZ, José; SANCHO CORBACHO, Antonio y COLLANTES DE TERÁN, Francisco: Catálogo arqueológico y artístico de la provincia de Sevilla. T. III. Sevilla, 1951, p. 166; MORALES MARTÍNEZ, Alfredo José et alii: Inventario artístico de Sevilla y su provincia. T. I. Madrid, 1982, p. 214; MORALES MARTÍNEZ, Alfredo José et alii: Guía artística de Sevilla y su provincia. Sevilla, 1981, p. 416; GARCÍA LEÓN, Gerardo: El arte de la platería en Écija. Siglos XV-XIX. Sevilla, 2001, p. 194; y GARCÍA LEÓN, G.: ficha catolográfica de la urna del Santo Entierro de Écija, op. cit., pp. 292-293.

${ }^{17}$ Ibidem, p. 292. 
Utrera. No hay demasiados datos sobre esta pieza ${ }^{18}$, "la gran urna de palosanto y carey, un carey macizo, virreinal, de color casi naranja" que "fue regalada por el marqués de las Amarillas, don Agustín de Ahumada y Villalón”, virrey de la Nueva España a mediados del siglo XVIII ${ }^{19}$. Algo anterior es la urna de la antigua cofradía del Entierro de Cristo y Nuestra Señora de las Tres Necesidades de Granada, de concha de carey y fina labor de platería, que se estrenó en la Semana Santa de 1676, siendo completada y rematada en 1691 por Manuel Valdés ${ }^{20}$.

Fuera del ámbito andaluz tan solo es posible mencionar la de Salamanca, obra anónima realizada con anterioridad a 1679, donada a la cofradía de la Santa Vera Cruz por Lorenzo García y Josefa de Aragón, como reza una inscripción en su interior. Se trata de una urna de base trapezoidal, realizada en madera de ébano y carey. Separando las ventanas hay columnillas sobre ménsulas con basa y capitel de plata. Entre los marcos de los cristales hay floroncillos y festones de plata $^{21}$.

Sin temor a equivocarnos, es posible afirmar que todas estas urnas han de considerarse piezas excepcionales en su género ${ }^{22}$. Por su parte, la urna de Logroño también se erigió en referencia artística. Evidentemente no estaba al alcance de cualquier cofradía fabricar una urna con materiales tan ricos como el carey y la plata, pero ello no fue óbice para que comenzara a imitarse. Así ocurrió, de manera muy clara, en el caso de la cercana localidad de Navarrete, donde se mandó fabricar una urna idéntica a la de Logroño, siendo luego policromada imitando el carey. La imitación del carey se realizaba antiguamente aplicando laca sobre papel vegetal, siendo sorprendente la habilidad de algunos artesanos al ejecutar este procedimiento ${ }^{23}$. Resulta así, en cierta manera, justificable el error cometido por parte de los responsables del Inventario de Logroño y su provincia que indican, al referirse a la urna del Santo Sepulcro de la iglesia parroquial de la Asunción

18 "Magnífica urna de carey y plata, obra del siglo XVIII" es lo único que afirma Julio Mayo Rodríguez, en SÁNCHEZ HERRERO, José; RODA PEÑA, José y GARCÍA DE LA CONCHA DELGADO, Federico (dirs.): Misterios de Sevilla. T. V. Sevilla, 2003, p. 482.

${ }^{19}$ DE LAS CUEVAS, José: "La Semana Santa de Utrera”, en $A B C$ (ed. Sevilla), no $17.034(1 / 4 / 1958)$, p. 20.

${ }^{20}$ BERTOS HERRERA, M Pilar: Imaginería y platería de la Semana Santa de Granada. Granada, 1994, pp. 187 y 252; y LÓPEZ-GUADALUPE MUÑOZ, Miguel Luis y LÓPEZ-GUADALUPE MUÑOZ, Juan Jesús: Historia viva de la Semana Santa de Granada. Arte y devoción. Granada, 2002, pp. 137-142 y 523.

${ }^{21}$ BLÁZQUEZ, Francisco Javier y MONZÓN, Luis: Semana Santa Salmantina. Historia y Guía ilustrada. Salamanca, 1992, pp. 82 y 118.

${ }^{22}$ CARRERO RODRÍGUEZ, J.: "La urna del Santo Entierro de Sevilla y otras...", op. cit., pp. 27-34.

${ }^{23}$ GAÑÁN MEDINA, Constantino: Técnicas y evolución de la imaginería polícroma en Sevilla. Sevilla, 1999, p. 220. 
de Navarrete, que se trata de un "sepulcro-vitrina con salomónicas, chapada en carey" 24 . Respecto al mueble que lo aloja, indica que se trata de un "retablo de zócalo, cuerpo y ático, con columnas salomónicas, barroco de fines del XVII", lo que coincide en fecha perfectamente y también por cuanto se refiere a las características formales con la obra de Francisco de la Cueva, permitiendo imaginar cómo se hallaría el Sepulcro de Logroño y la imagen de la Virgen de la Soledad en el armario fabricado por este artista hasta que se levantó el actual retablo neoclásico ya en la nueva capilla de los Ángeles.

Fecha de recepción: 7 de enero de 2017

Fecha de aceptación: 20 de enero de 2017

${ }^{24}$ MOYA VALGAÑÓN, José Gabriel (dir.): Inventario artístico de Logroño y su provincia. T. III. Madrid, 1986, p. 94. 


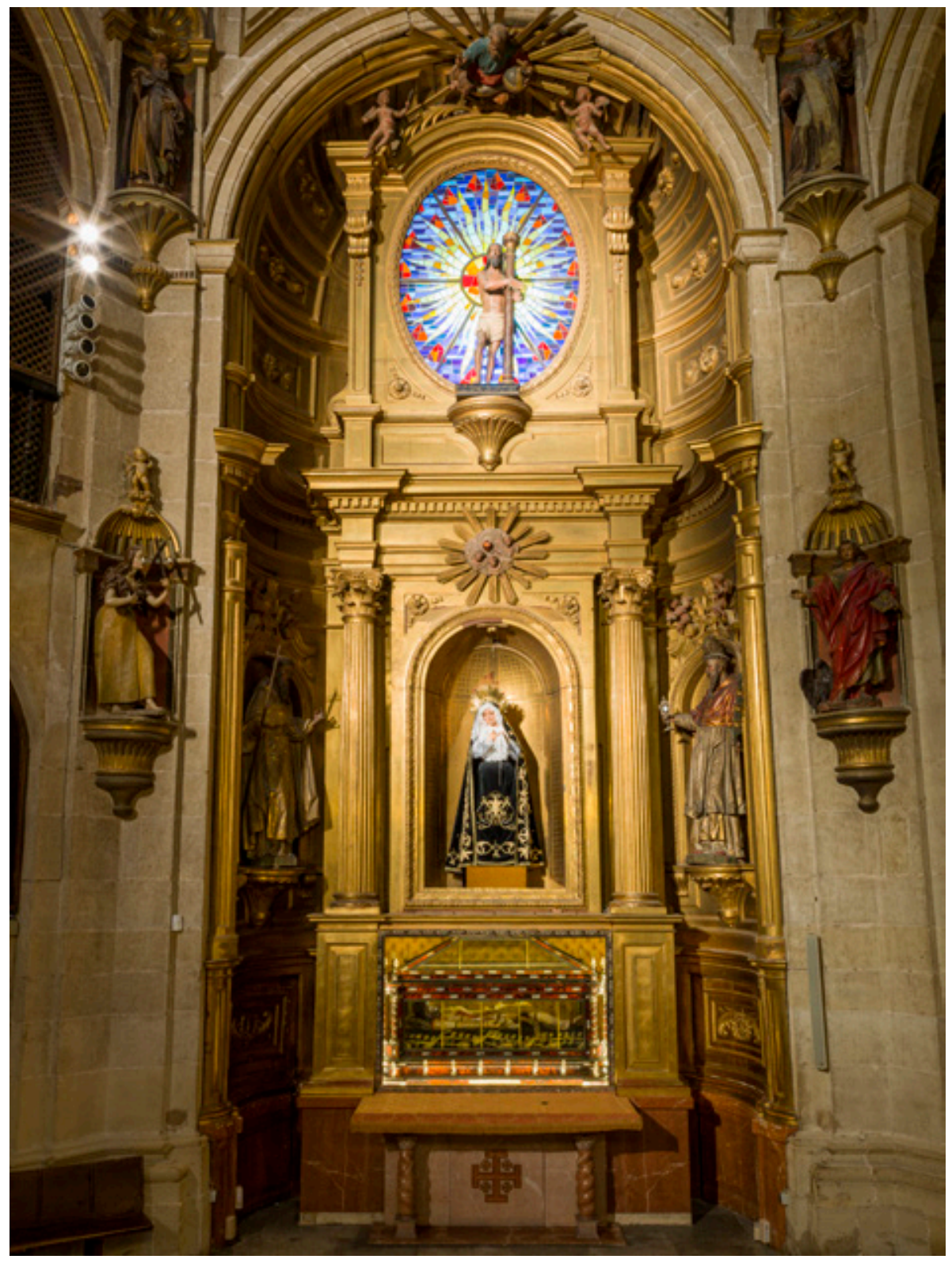

Figura 1. Retablo del Santo Sepulcro, Concatedral de Santa María de la Redonda, Logroño. Foto: José Antonio López Hueto. 


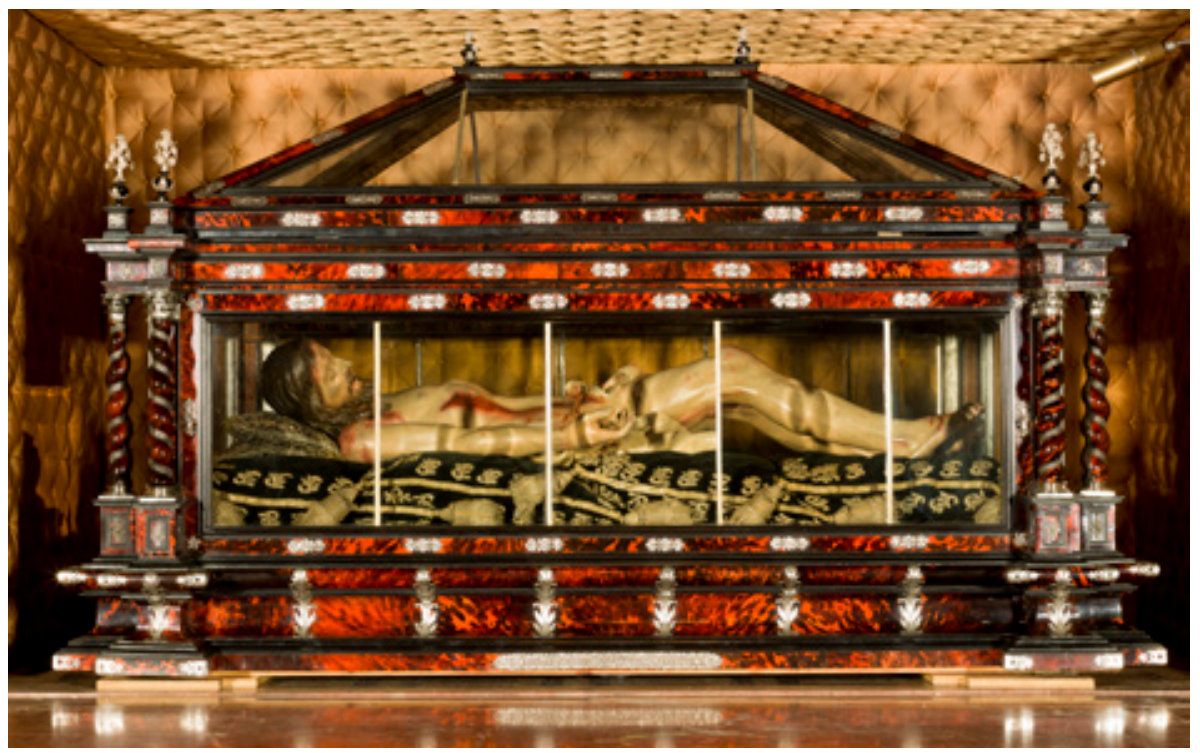

Figura 2. Santo Sepulcro, Concatedral de Santa María de la Redonda, Logroño. Foto: José Antonio López Hueto.

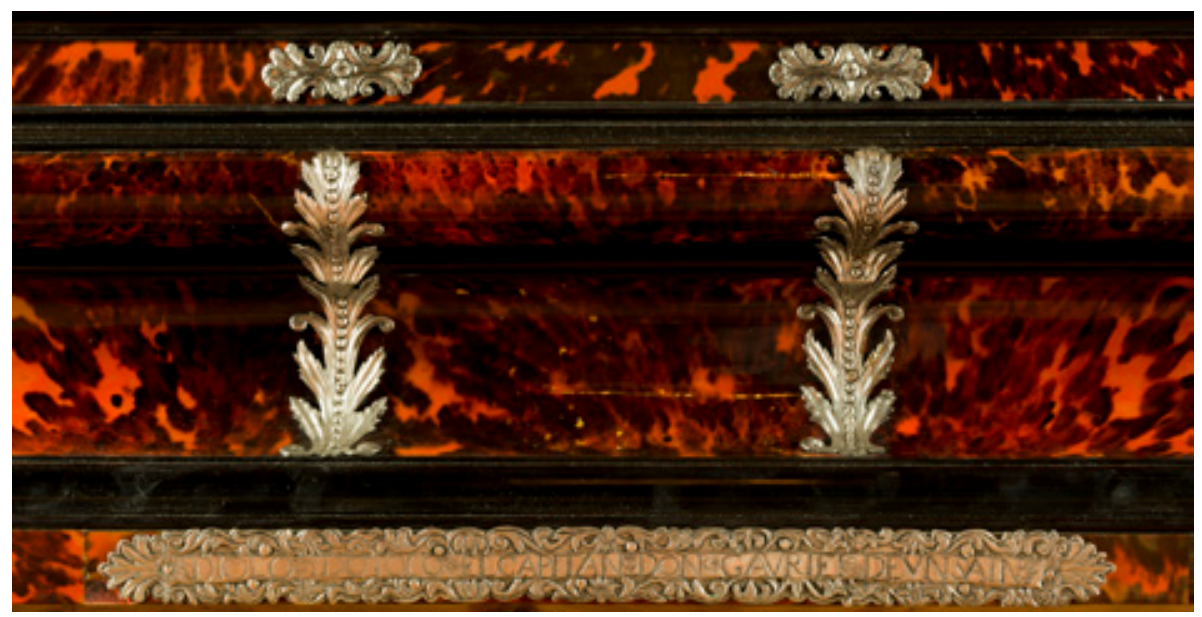

Figura 3. Detalle de una de las cartelas de la base de la urna del Santo Sepulcro, Concatedral de Santa María de la Redonda, Logroño. Foto: José Antonio López Hueto. 


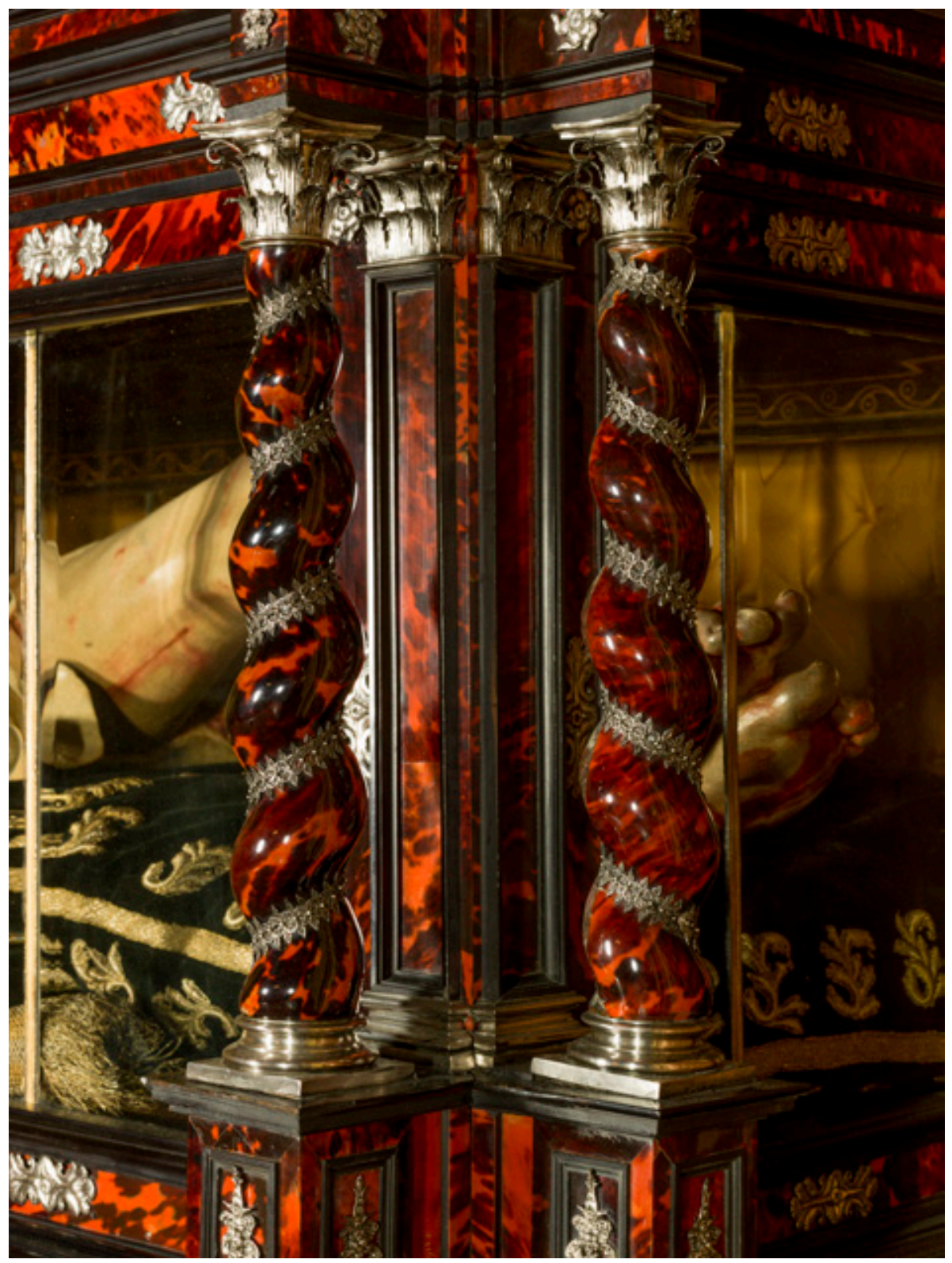

Figura 4. Detalle de las columnas salomónicas de la urna del Santo Sepulcro, Concatedral de Santa María de la Redonda, Logroño. Foto: José Antonio López Hueto. 


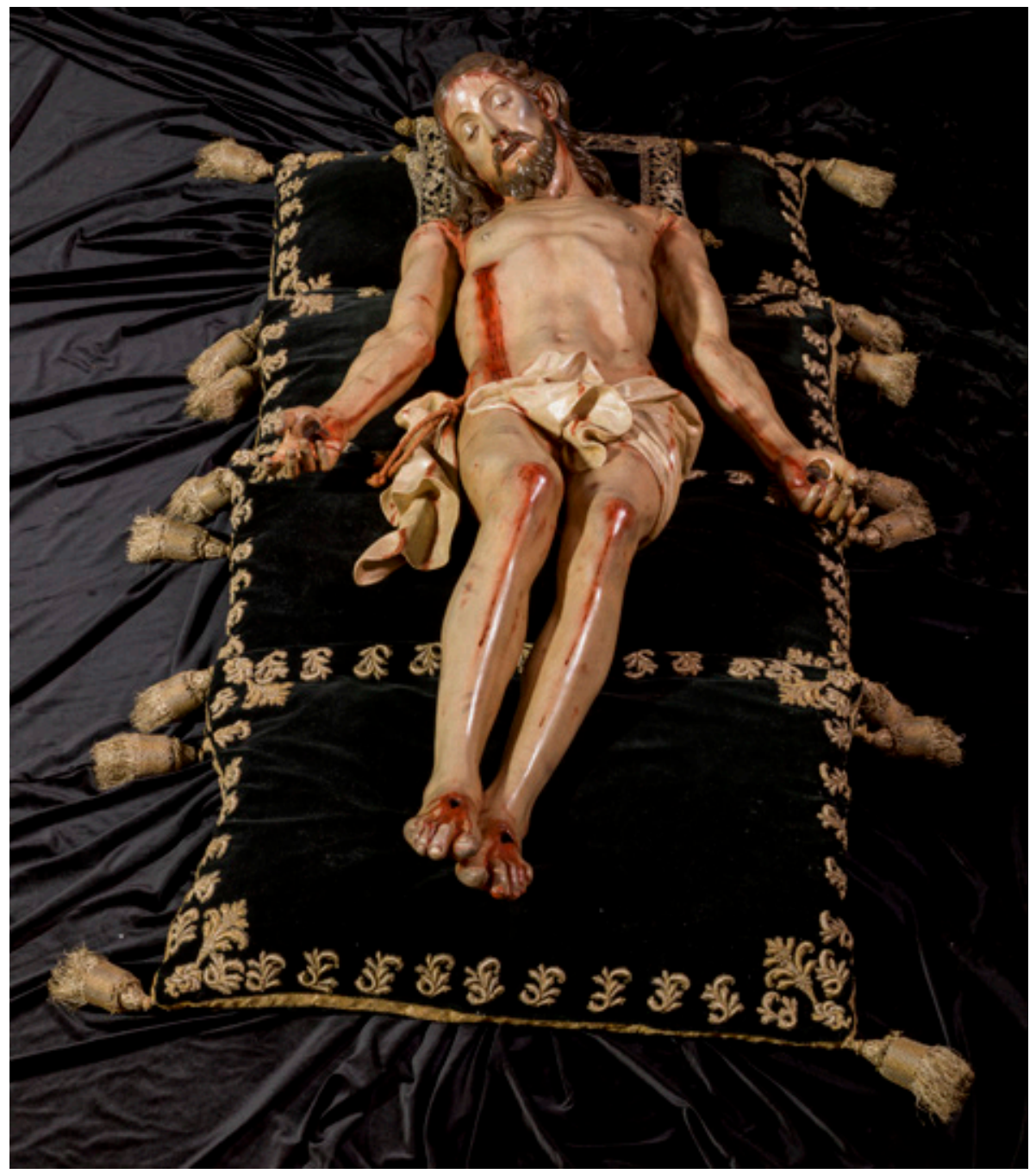

Figura 5. Cristo yacente, Concatedral de Santa María de la Redonda, Logroño. Foto: José Antonio López Hueto 